\title{
CRITICAL ANALYSIS AND DIGITAL RECONSTRUCTIONS OF ALBERTI'S ARCHITECTURES BY THE USE OF 3D MORPHOMETRIC INTEGRATED SURVEY DATABASE
}

\author{
F. Ferrari ${ }^{a}$, M. Medici ${ }^{\text {a, * }}$ \\ a Department of Architecture, University of Ferrara, Italy - (federico.ferrari, marco.medici)@unife.it
}

Commission II

KEY WORDS: 3D survey, laser scanner, Leon Battista Alberti

\begin{abstract}
:
Since 2005, DIAPReM Centre of the Department of Architecture of the University of Ferrara, in collaboration with the "Centro Studi Leon Battista Alberti" Foundation and the Consorzio Futuro in Ricerca, is carrying out a research project for the creation of 3D databases that could allow the development of a critical interpretation of Alberti's architectural work.

The project is primarily based on a common three-dimensional integrated survey methodology for the creation of a navigable multilayered database. The research allows the possibility of reiterative metrical analysis, thanks to the use of a coherent data in order to check and validate hypothesis by researchers, art historians and scholars on Alberti's architectural work.

Coherently with this methodological framework, indeed, two case studies are explained in this paper: the church of San Sebastiano in Matua and The Church of the Santissima Annunziata in Florence. Furthermore, thanks to a brief introduction of further developments of the project, a short graphical analysis of preliminary results on Tempio Malatestiano in Rimini opens new perspectives of research.
\end{abstract}

\section{INTRODUCTION}

In recent years we mainly assisted in the development of two different modelling procedures for virtual reconstruction of Cultural Heritage assets: from one side the main aim is the visualization for dissemination purposes, on the other one, the overall goal is the analysis of building phases over time, in particular for uncompleted buildings and architectural complexes or those that were modified by human actions. Furthermore, in the first case, it clearly emerges that the digital reconstruction is primarily based on already known data on which representation and communication techniques are applied, without any critical interpretation of evolution hypothesis (El-Hakim et al., 2004). In the second one, instead, the digital reconstruction is performed starting from $3 \mathrm{D}$ data capturing techniques for the assessment of the building and the consequent set up of reconstructive analysis and evolution hypothesis (Guidi \& Russo, 2011). For this reason, the workflows are profoundly different. The output for visualisation purposes should be simplified in order to become effective, engaging and easy to understand. These virtual reconstructions are targeted on the end-user and must be compliant with the media through which they will be distributed. Conversely, the output for analytical purposes should be really accurate, comparable and updatable. Here the metrical accuracy, as well as data coherence achieved by metadata and paradata archiving, are extremely valuable features.

This essay proposes a critical-interpretative approach mainly centred on the second workflow, where the information process is aimed at understanding the architecture of Leon Battista Alberti. As well, a downscaling approach is also proposed in order to re-use such data for dissemination purposes.

\section{THE ALBERTI PROJECT}

The project, carried out by the DIAPReM Centre of the Department of Architecture of the University of Ferrara, in collaboration with the "Centro Studi Leon Battista Alberti" Foundation and the Consorzio Futuro in Ricerca, is part of a more complex research started in 2005 , for the creation of $3 \mathrm{D}$ databases that could allow the development of a critical interpretation of artistic influences and architecture.

Alberti's buildings, designed or simply ascribed to him, are often deeply documented in history and, even if a lot of studies were performed on them, most of the times they are surveyed with different methodologies and technologies. In order to achieve an effective comparability between them and check theories, shapes and proportions, a 3D laser scanner campaign was arranged during years, based on a solid expertise of the DIAPReM Centre (Bulgarelli et al., 2006).

\subsection{An Alberti's Architecture interpretation}

In 1860, Jacob Burckhardt, in the first part of his fundamental essay "The Civilization of the Renaissance in Italy" (Burckhardt, 1914), titled "The State as a Work of Art", has suggested an interpretation of Alberti's architectures that, even if outdated, is full of a great charm. For the Swiss scholar, Leon Battista Alberti embodies a "multialtero man", "a universal man", a personality with multiple aptitudes, and great "versatility". Humanist, writer, mathematician, theoretical of arts, scholar of architecture, keen observer of the events of his time, Leon Battista Alberti is a man of great modernity. It's no coincidence that Cristoforo Landino, in the end of the fifteenth century, gets an extraordinary picture of Alberti's peculiarities by the metaphor of the "chameleon" (Landino, 1974): camouflage, experimentalism, the endless variety of linguistic styles and thematic registers. However, if the variety is the code of the fifteenth century, when it is mixed together with the

\footnotetext{
* Corresponding author
} 
experimentalism and especially with the idea that bonae artes are in medietas, it is still the code of our times. The metaphor used by humanists to express their concept of art and imitation is the ancient one of the bee (Bozzola, 2012). This metaphor, however, makes clear only some stages of the process. It explains to us that each work comes from other works, that any new text is an anthology of other texts, that exploited works are pollen, while the end result is honey, a different and better product. Alberti goes over the metaphor of honey and, instead, he carries on and deepens one of the mosaics. Indeed, the metaphor of honey has the limit that, while admitting a process of transformation, it says nothing about that process, while the metaphor of the mosaic reveals largely the mechanism of creation. Alberti asserts that the culture of the past is like a temple, but the mission of the modern intellectual is to break it into pieces. The transformation of the materials of the past in mosaic tiles is, indeed, the first stage of the new building. The second is to select in choosing between reuse materials, only what it's needed for the new building. The third, instead, consists of assembling the tiles on the basis of a concept.

\subsection{The survey campaign and post-processing activities}

Since 2005, in the first phase of the project, the 3D integrated survey for the reconstruction aimed analytical purposes (metrical checking, evolution hypothesis, etc.) was carried out.

In that phase the following surveys were performed:

- Sant'Andrea and San Sebastiano in Mantova;

- Santissima Annunziata in Firenze;

- San Martino in Gangalandi in Lastra Signa;

- the bell tower of the Duomo of Ferrara;

- Tempio Malatestiano in Rimini;

- the façade of Santa Maria Novella in Firenze.

The survey phase was completed in few years (2005-2009) and, after that, in the second phase, a 3D database was arranged in order to ensure the data readability, upgradability and repeatability as well as the multilayer organisation for different users: researchers, historians, technicians and asset managers. Building up the database by the aggregation of point cloud models, survey metadata, topographic data and photos allowed different integrated queries of all kind of data, starting point for the analysis of architectures and their valorisation (Bonora et al., 2005) as well as their management.

However, the research is still ongoing and the preliminary results that will be shown in this paper are referred to:

- evaluation of the metrical analysis developed by Calzona e Volpi Ghirardini (Calzona \& Volpi Ghirardini, 1994) on San Sebastiano in Mantova;

- comparative analysis between the 3D point cloud for laser scanner survey and virtual reconstruction in $\mathrm{H}$ BIM model of hand drawings by Antonio Labacco on San Sebastiano in Mantova;

- analysis of Tribuna della Basilica della Santissima Annunziata (Heydenreich, 1930) in Firenze in relation to what written by Alberti about central plan churches on the "De re aedificatoria";

- morphological analysis on Tempio Malatestiano (Hope, 1992) in Rimini in order to evaluate the relation between the Alberti's envelope and the preexistent San Francesco church.

\section{INTEGRATED SURVEY METHODOLOGY}

Being able to record the geometric memory of all the architectures ascribed to Leon Battista Alberti may seem an ambitious aim (Apollonio et al., 2014). Methodologically, surveys should share the same workflow and comparable instruments, in order to collect homogeneous morphometric data, on which several queries could be performed. As well, related topographic and photographic data should be collected and archived for a comprehensive documentation. Indeed, the purpose of the research is to create a navigable multi-layered database, primarily designed for the use by researchers, restorers, art historians and scholars (Figure 1).

Actually, the overall database of the Alberti architectures already includes today approximately 2.5 billion spatial coordinates defining descriptive-metric models which allow a multi-scale analysis and representation of architectures.

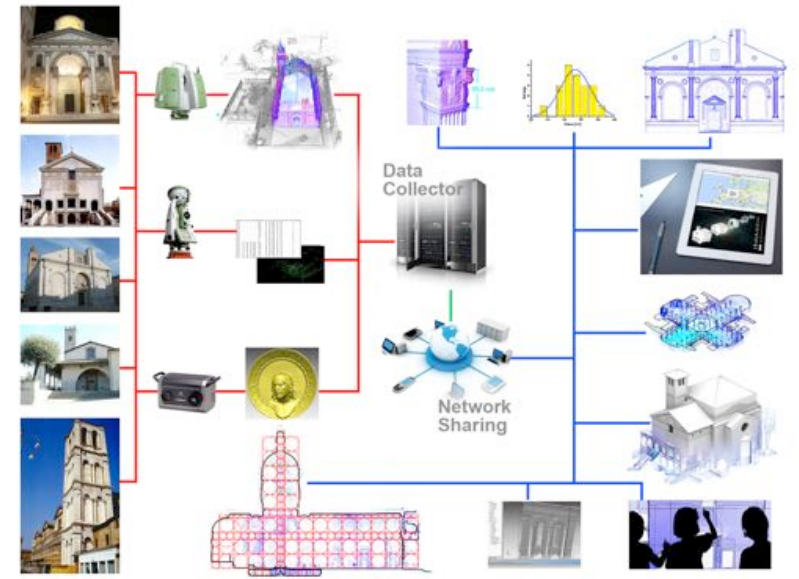

Figure 1: Diagram of the Alberti Project by the data collection in $3 \mathrm{D}$ databases and their exploitation for several purposes.

\subsection{Data capturing techniques}

The complex volumetric articulation of surveyed buildings, due to the typological variation of the Alberti's architectures, addressed the research towards a synergic integration of different survey methodologies (Docci, 2005):

1) the 3D laser scanner data capturing by different instruments;

2) the topographic method for scan registration and accuracy enhancement;

3 ) the photographic survey to check the state of conservation of materials and decorations as well as to extract orthophoto images.

The non-stop development of data capturing tools during the on-field and post-processing work (2005-2012) was the main reason to evaluate, re-arrange and set-up several data capturing procedures in order to normalise data (i.e.: reflectivity index). This led to the need of setting up a procedure that could ensure, freely from technological obsolescence, data homogenization by a methodological point of view. Such normalisation becomes essential to perform a comparison of metrical analysis on Alberti's architectures, especially looking at several previous analysis (Tavernor, 1985) (Volpi Ghirardini, 2001). Furthermore, it should be considered that Alberti's design process was far away from our current practice, he didn't see anyone of his architectures completed in his life and the "De re aedificatoria" (Alberti, 1966) is the only interpretation key of his design-thinking by his architectures. 
The technological evolution for 3D data capturing was, from the beginning of the research, one of the most innovative elements that allowed to introduce high definition metrical and morphological data as an essential aid to the development of 3D databases that could, over the time, build up an archive of the architectural geometric memory and establish the starting point for metrical, metrological and reconstructive analysis.

\section{THE SAN SEBASTIANO CHURCH}

The church of San Sebastiano dates back in 1460 and it is the first architecture based on Alberti's design that was built in Mantua. The drawing by Antonio Labacco, from the early sixteenth century, which represent the plan of the church, ensures the originality of the project with excellent reliability. The start of construction was immediately troubled, probably due to the inclusion of the underground floor, not included in the first design.

Despite the layout of the first floor consistently match the drawing of Labacco, subsequent corrections show, in practice, a new way of Alberti to lead the construction site without the constant presence of the designer.

After a fast begin due to Ludovico Gonzaga's interest in the new church of Sant'Andrea, the slowness in the works' progress left unfinished the San Sebastiano church, when his death came, and in particular, the dome, shown in the drawing of Labacco, was missing. The church completion was carried out by Canons Regular of the Lateran, starting from 1488, but it's still unclear if they were following the Alberti's design.

Furthermore, the restoration by Andrea Schiavi (1924-1925), in order to free up the building from adjustments and additions, heavily influenced his current appearance (Borsi, 1996).

\subsection{Architectural analysis by literature review}

As stated by Alberti himself ${ }^{2}$, he was seeking a numerically expressible order. For this reason, in order to accomplish the iconometric analysis of San Sebastiano (Calzona \& Volpi Ghirardini, 1994), Volpi Ghirardini, begins, first of all, from the proportional study of the drawing by Antonio Labacco, in order to find any confirmation on the architecture of the temple itself. Furthermore, according to (Wittkower, 1964) who reaffirms that the act of measuring is a substantial demonstration of proportions, Volpi asserts that survey and drawing historically produced are unreliable because the source is usually unknown and they don't express directly numbers captured on the building (Calzona \& Volpi Ghirardini, 1994).

These important considerations are shared in our project through different key elements such as the numerical value of the survey and not just the graphic representation. Furthermore, the orderliness and repeatability of measurement bring a great improvement to analysis thanks to the availability of a digital metric model of hundreds of thousands of measures: the database of San Sebastiano has, indeed, about 350 million threedimensional points. Nevertheless, this is a clear interpretation of the approach to the use of point clouds models as already treated by (Migliari, 2001).

\footnotetext{
2 "Natura emimoptima concupiscimus et optimis cum voluptate adheremus. Neque in toto corpore aut partibus viget magis concinnitas quam in se ipsa atque natura; [...] Totam complectitur hominis vitam et rationes, totamque pertractat naturam rerum". Leon Battista Alberti, De re aedificatoria. IX, 5 (Alberti, 1966).
}

Starting from the 3D point cloud morphometric model, all necessary section plans and projection of the San Sebastiano church have been produced in $2 \mathrm{D}$ CAD format. It was also developed a three-dimensional BIM model of San Sebastian to further analysis on the building volume.

Obviously, not everything was measured, but only what has been deemed worthy. The interest for us is not to reproduce the building through an elaborate drawing: this is, if necessary, a secondary purpose. The primary challenge of this research is, of course, to analyse, verify, compare the variety of numerical data in order to set correct and verifiable hypotheses (Calzona, 1994) and became ourselves part of the process of growth and study as mentioned in the introduction in the humanistic metaphor of the bee.

\subsection{Checking the Alberti proportions}

Building the San Sebastiano, Alberti faces for the first time an ex-novo architecture. As shown by Labacco's drawing, the first design is very different from the church that we face today.

The crypt wasn't there, the central space was covered by a dome and there was double gable on the façade. The drawing is not a simple sketch, it shows dimensions in plan and elevation, measured in Mantuan fathoms (Calzona \& Volpi Ghirardini, 1994). Following the analysis of Volpi, one Mantuan fathom is equivalent to $46,69 \mathrm{~cm}$. Comparing the initial design with the current one, it's possible to note large differences in the elevation due to the addition of the crypt.

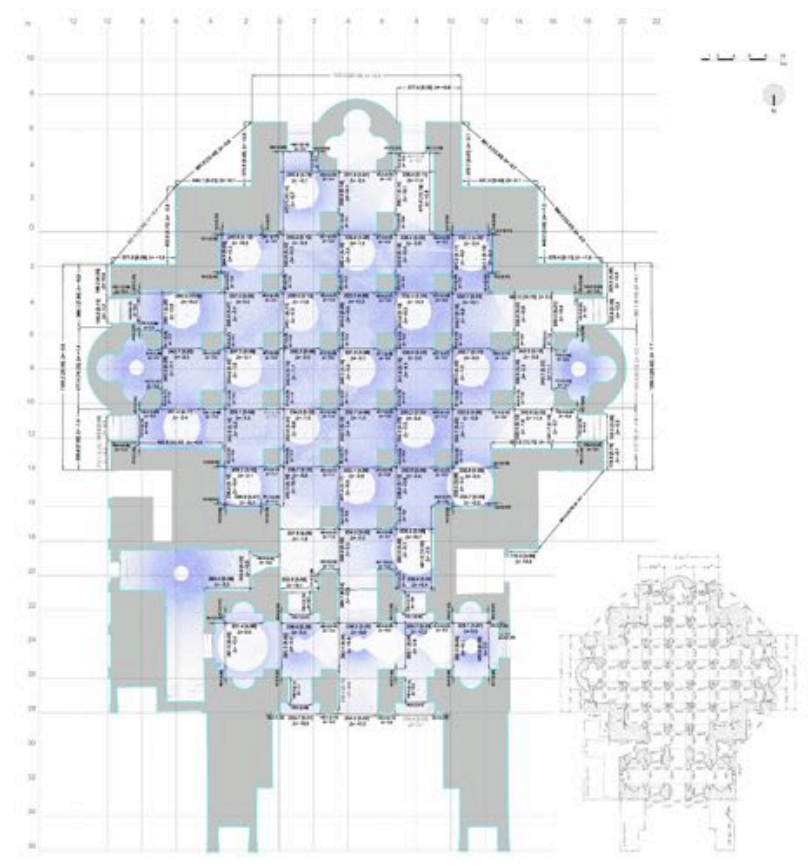

Figure 2: Analysis of the metric ratio of the crypt by the use of a plan section of the point cloud (3.307 meters beneath street level - original drawings scale 1: 100).

The drawing by Labacco allows to understand how the Alberti focused his interest on measures and ratio: for instance, the height of the chapels is twice the size of the narthex $\left(33_{1 / 2}\right.$ $\left.16_{2 / 3}\right)$. We can also find the 1:2 ratio between the façade and the main body of the building and, once again, in the crypt that is high $8_{1 / 3}$ or half of the narthex (Figure 2).

Despite the remaking of the floor by the Schiavi, this could be a clue that Alberti designs the crypt too, even if only at a later 
time. Once established heights, the architect divides the internal space in order to reproduce, between base and height, the 3:5 ratio, that rules all relations of the Labacco's drawing. An example is given by the distance between of the columns of the crypt that is equal to 5 fathoms. Indeed, the ratio is $5: 81 / 3$ and it equals to $3: 5$.

Through the same method, Alberti gets the height of the chapels, referenced to the height of the narthex, with the following proportion:

$$
16_{2 / 3}: x=3: 5
$$

where the result, indeed, is equal to $27_{1 / 2}$.

Furthermore, it is also possible to set another proportion that Alberti uses: 4:5, that is the average proportion of 3:5, or $(3+5) / 2=4$. And if we try also to relate all heights of San Sebastiano each other, we can find following valuable results, that confirm what stated before (Figure 3, Table 4-5).

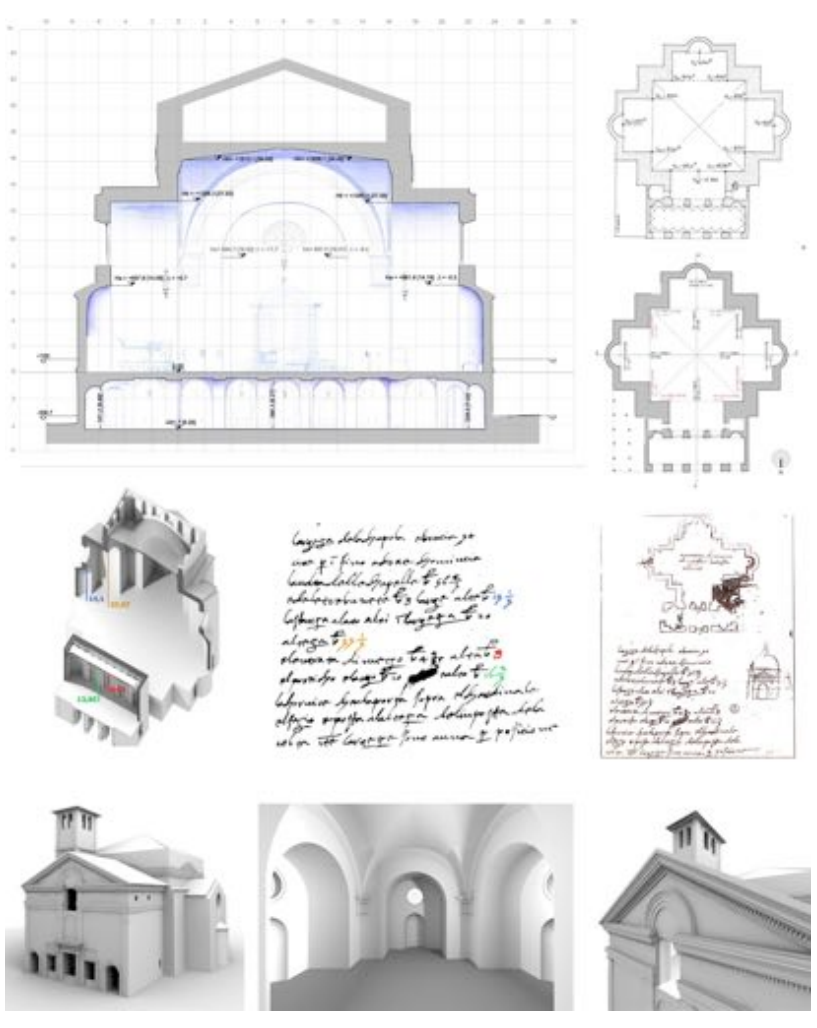

Figure 3: Comparative analysis on the heights gathered by a cross section of the point cloud (original drawings scale 1: 100). Double check of Labacco's drawings by the use of a BIM model built by the point cloud.

\begin{tabular}{|l|c|}
\hline Measurement & Heights in Mantuan fathoms \\
\hline Internal crypt & $8_{1 / 3}$ \\
Internal tribuna & $13_{1 / 3}$ \\
Inner narthex & $16_{2 / 3}$ \\
Internal chapels & $27_{2 / 3}$ \\
Extrados inner frame & $34_{1 / 2}$ \\
above vaults & 46 \\
Inside of the vault of \\
the central square
\end{tabular}

Table 4. Heights measurement in San Sebastiano

\begin{tabular}{|c|c|}
\hline Heights & Ratio \\
\hline $8_{1 / 3}: 13_{1 / 3}$ & $3: 5$ \\
$13_{1 / 3}: 16_{2 / 3}$ & $4: 5$ \\
$16_{2 / 3}: 27_{2 / 3}$ & $3: 5$ \\
$27_{2 / 3}: 34_{1 / 2}$ & $4: 5$ \\
$34_{1 / 2}: 46$ & $3: 5$ \\
\hline
\end{tabular}

Table 5. Heights ratio verification

After this verification carried out by ratio's analysis, we can see how Alberti was searching for his concinnitas through the proportion (Tavernor, 1985).

\section{THE SANTISSIMA ANNUNZIATA CHURCH}

The Church of the Santissima Annunziata in Florence is part of Piazza della Santissima Annunziata. The square, with arcades on three sides, was designed with standards incorporating stylistic harmony with the prospective scenery in Via dei Servi and framing the Brunelleschi's dome of Santa Maria del Fiore. Its history began around the end of the thirteenth-century: founded in 1250 , the oratory received the papal privilege of collecting offers for the endowment of S. Maria dei Servi (Casalini, 1967). In 1286, the building appeared to be four times bigger from the original oratory, incorporated in the construction (Casalini, 2015). Between 1320 and 1340 an additional cloister with a double open tribuna was added and a further expansion phase occurred in 1384, most likely following the gothic project (Casalini, 2015) of the Superior General of the Ordine dei Serviti padre Andrea of Faenza (Bulgarelli et al., 2006).

The codice rustici (ca.1420), preserved in the Florentine seminary of Cestello, reports an architectural design of the SS. Annunziata, a witness for the state of art of the Sanctuary before the 1444 restoration. In this same year the Marquis of Mantua, Gianfrancesco Gonzaga, offered an amount of money to intervene in the complex: the reasons for a complete makeover could be due to the continuous need for more space and more decoration of the sacred location. This influenced the interest of the lords of Mantua for the Florentine church, which created the beginning of a long sequence of interventions starting with the aisle, then the construction of the circular tribuna. This was a difficult and expensive undertaking of the overall architectural makeover called for Michelozzo, whose job consisted in the expansion of the church and sacristy, the building of a lavish tabernacle in the shape of a small temple for the miraculous image of the Annunziata, the remodel of the atrium in front of the Sanctuary, the construction of the oratory of St. Sebastian, the restoration of the Great Cloister, the convent cells, and the creation of a wide, bright and comfortable library in an environment conditioned by old structures (Casalini, 2015).

Michelozzo's idea was to add to the temple, in place of the apse, a building with a central plan, that did not disturb the architectural unity. The tribuna had to remain independent and self-supporting (Heydenreich, 1930). It was a singular and innovative work in Florence. This lead to much criticism, hampering the progress of the work. Many other economic factors created a series of long delays in the completion of the tribuna (Casalini \& Parronchi, 1977). The controversy between the artists, for the approval of the old or new design, were rampant to such an extent that the Marquis of Mantua, uncertain of what to do, complained to the Florentine Signoria. In 1469 Alberti (Bulgarelli et al., 2006) stayed in Mantua and the 
Marquis (Gonzaga) took advantage of the architect's suggestions for the Florentine Tribuna. It is still not possible to accurately determine how much Alberti modified the original design of Michelozzo from the reconstruction. The final work resumed in 1471 under the responsibility of the architect, in spite of the violent controversy that followed Alberti's proposal: increasing the number of chapels of the tribuna to nine and directly joining them to the Rotunda within the longitudinal body of the church with a large arch.

The elevation of the entablature had two orders: one on top of the arches and the other on the springer of the whitewashed roofing of the cupola. Between the two trabeations ran a series of arched windows; creating the choir for the friars in the middle with a separation wall, a sort of ambulatory ring in front of the chapels. Outside, the Annunziata tribuna integrated its faceted white volume with the city's panorama. However, the addition of this building with the rest of the church was not as simple as it seemed at first sight: raising and enlarging the major arc while also raising the nave by about 8 meters. Completion of the architectural work was in 1481 (Casalini, 1967). By utilising a concrete dome, the tribuna clearly reflects ancient architectural techniques of construction - as exemplified by the Pantheon - free from Florentine influence. In this way, the Church of the Annunziata created a composite system, consisting of a longitudinal nave and the domed tribuna, which Alberti had imagined for the Tempio Malatestiano in Rimini, reminiscent of late and ancient origins.

\subsection{Checking the Alberti proportions: size and shape}

The survey of the monumental complex focused on knowledge of architectural spaces has allowed an understanding of how Leon Battista Alberti expressed his inventiveness through form, demonstrating how architecture could change by utilising precise consistency. Not only did the realised forms meet the specific needs for which they were created, they also represent the language chosen by the architect within the humanist cultural context required by a building with those specific needs.

The intervention of metric acquisition of distances and directions through the three-dimensional scanning system has allowed acquiring numerous amounts of data in a short amount of time. The data collected were spatial coordinates precise enough for the architectural topic. Theoretical studies regarding the general problem of proportion and of scaling patterns of monumental buildings (De Angelis D'Ossat, 1982) appeared rare and were often vague. Hoverer, the analysis of the database using a metrology key allowed an understanding of the metric concordant language used by the architect inside the building. It is necessary to highlight that although Alberti defined a proportionate scale in his drawings, during construction, the buildings underwent a process of adaptation to the area, with further changes. This was because Alberti did not like to direct the execution of his projects. The metrological survey evaluated the proportion of the chapels in the tribuna between full and empty, and the height of the dome in relation to the plan size (Figure 6).
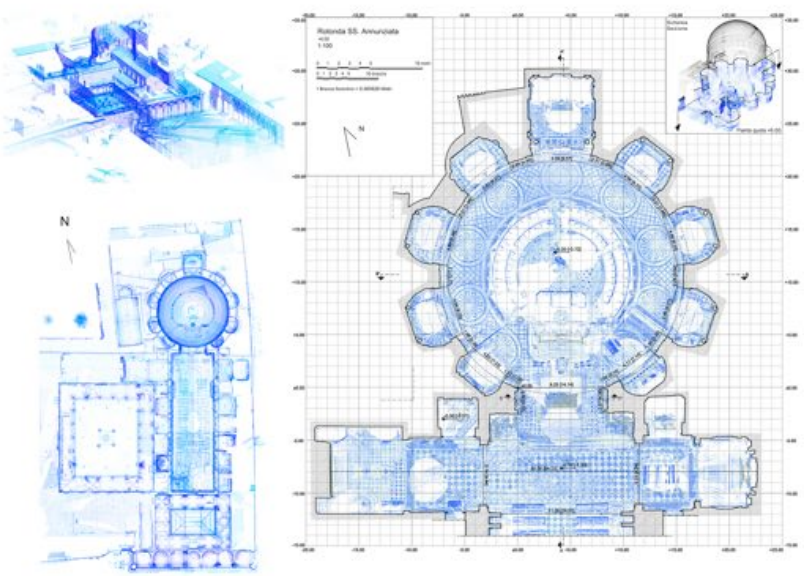

Figure 6: General plan and focus on the Tribuna of the Basilica of Santissima Annunziata in Florence, gathered from the 3D point cloud model (original drawings scale 1: 100).

Alberti addressed the issue of the chapel's arrangement stating that "if the plan is to be multi-faceted, the relation will be one to three" (Alberti, 1966). Inside the tribuna, the relation is structured into nine chapels with dimensional "delta" that are attributable to the realisation of the construction site. In the Chapel of Santa Lucia the size of the solid $\mathrm{S}=3.95$ (Florentine fathoms) and the size of the void $\mathrm{V}=8.27$ (Florentine fathoms). When added up, $\mathrm{T}=\mathrm{S}+\mathrm{V}=3.96+8.27=12.23$ and weighted with the solid $\mathrm{T} / \mathrm{S}=12.23 / 3.96=0.3237$ tended to conform to the proportion of $1 / 3$, set out in Chapter IV of Book Seven (Figure 7). One Florentine fathom is equivalent to $58.3626 \mathrm{~cm}$.

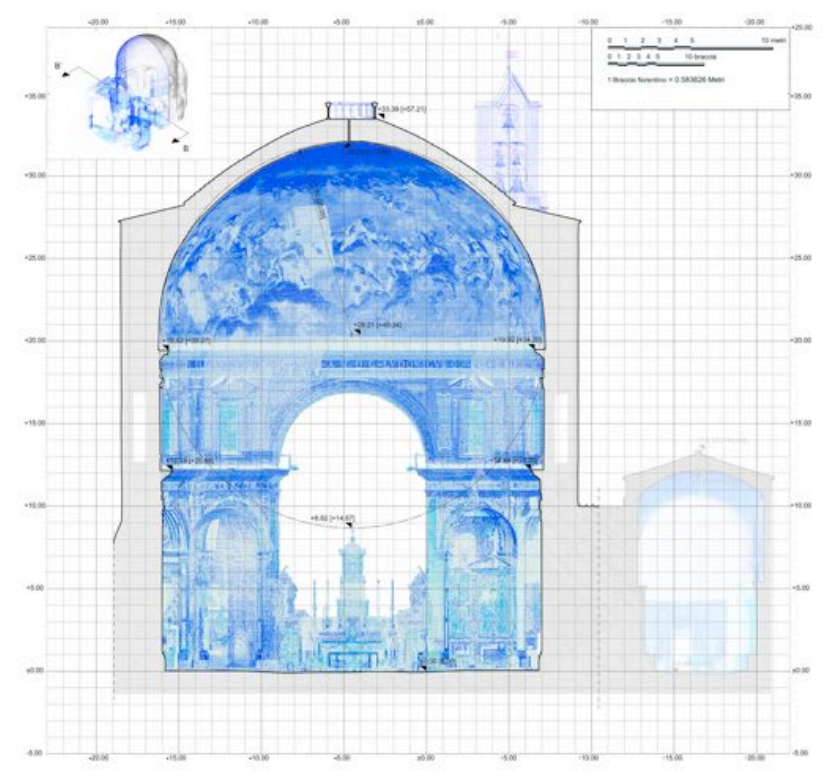

Figure 7: Cross section of the the Tribuna of the Basilica of Santissima Annunziata from the 3D point cloud mode (original drawings scale 1: 100).

On further evaluation, the size of the volume of the tribuna, Alberti stated in Chapter X of Book Seven that "the height of the wall from the beginning of the vault, in the round churches, must be equal to one-half, two-thirds or three-quarters of the diameter in the plant." With the 3D scanning, the metrological survey highlighted that the Architect dimensions of the components were as follows: height of the springer $\mathrm{H}=35.00$ 
(Florentine fathoms), plant diameter $\mathrm{D}=39,47$ (Florentine fathoms), and the relation between the parties $\mathrm{R}=\mathrm{H} / \mathrm{D}=35.00$ / $39.47=0.8869$. It is possible to note that the ratio is likely similar to $9 / 10$ rather than to a half, two-thirds or three-quarters of the diameter.

\section{THE TEMPIO MALATESTIANO}

The Tempio Malatestiano, in Rimini, was originally a thirteenth-century Gothic church belonging to the Franciscans, that was built on the previous church of Santa Maria in Trivio (1256). The San Francesco church had a rectangular plan, without side chapels, with a single nave ending with three apses. Like in other Franciscans churches, in XIV century, two chapels were built on the right side and then on the left one too. Around 1450, Sigismondo Pandolfo Malatesta commissioned to Leon Battista Alberti the renovation of the building. Alberti built a kind of marble envelope around the church, in order to protect and renew the previous Franciscans ecclesial architecture.

The main theme of this renovation is the arch, that significantly characterises the façade by a triumphal one and sides by arcades, theoretically corresponding with secondary naves (Fiore, 2006).

The large arcades on the sides, that are reminiscent of inner arcades of the Roman Colosseum (Grassi, 2007), don't hide the original framework but simply add a new architectural appearance, leaving the graves unchanged.

In this way, the 3D survey became an analysis instrument of the architectural space, of the metrical and morphological relation between design and realisation. Nevertheless, it's worth focusing on the relation between the San Francesco church and the Tempio Malatestiano, particularly referring to side windows. Indeed, the Albertian envelope becomes a new rhythm and defines a new order of the renewed architecture, transformed and reinterpreted by the Alberti's design (Figure 8).
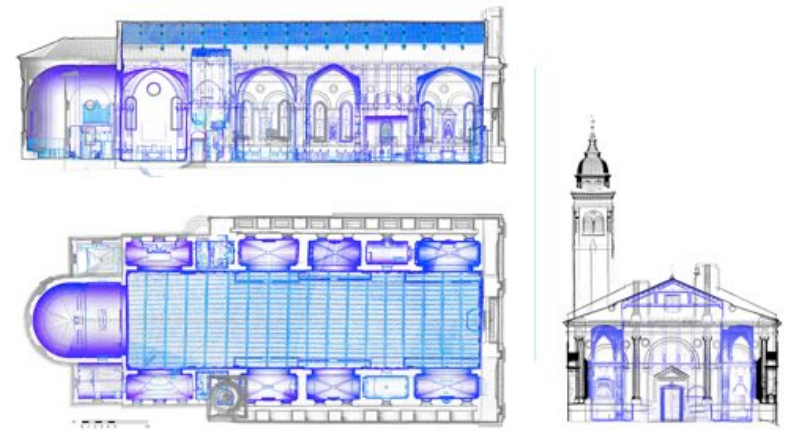

Figure 8: Comparative graphical analysis between the original framework of San Francesco church (blue point cloud) and the new rhythm given by the Albertian envelope (black point cloud).

Several analyses by scholars identify in the renovation project a proposal for a circular dome (Cardamone, 2016) (Brandi, 1956) (Ragghianti, 1965) (Tavernor, 1998), as seen in the Santissima Annunziata, but no one solves the connection with the nave as declared by (Frank, 1910) in his reconstruction hypothesis of the Tempio Malatestiano (Fiore, 2006).

Therefore, one of the next outputs of this research will be the checking of such kind of hypothesis thanks to the use of 3D survey, point cloud database and virtual reconstruction.

\section{CONCLUSIONS}

The research framework allows the possibility of reiterative metrical analysis, thanks to the use of a coherent database, built on an accurate methodology of survey (Balzani, 2006), in order to check and validate what already explained on Alberti's architectural work.

Referring to San Sebastiano, as predicted by (Volpi Ghirardini, 2001), the analysis showed little planimetric variations between designed and surveyed measures (around few centimetres) due to progressive measurement techniques used on the field during the construction. Looking at the elevation, variations slightly increase in proportion to heights (excepting for underground vaults where variations are higher than a decimetre).

These results, as already shown in Table 5, made possible to link measurements to each other in order to check ratios gathered from the analysis of historical studies (Volpi Ghirardini, 2001).

Although it is difficult to make valid observations in the Rotonda della SS. Annunziata, as Alberti intervened on the building set by Michelozzo, the study highlights that the use of a geometric database, based on three-dimensional survey, which is coherent and homogeneous, are relevant to create a critical analysis of comparative testing between the principles set by De Re Aedificatoria and Alberti's architecture (Wittkower, 1964). Sometimes through inevitable, but necessary mediation, due to static and constructive requirements, architectures can be built maintaining the purity of the theoretical scheme. "During the Renaissance, the metric proportion was the guiding principle of order and reveals the harmony between all parties, and between the parties and the whole" (Wittkower, 1964).

Nevertheless, these preliminary results have already developed a critical approach to the understanding process based on an indepth knowledge of Alberti's work. Furthermore, the application of a normalisation process of captured data allows the comparison of different sources in order to perform really effective analysis on highly relevant architectures for our Cultural Heritage. As well, on the methodological side, the development of a comprehensive documentation process heavily contributed to the Data Acquisition Protocol developed within the INCEPTION project funded by the EU (Di Giulio et al., 2016), where the setting up for an optimized procedure of $3 \mathrm{D}$ data acquisition and 3D integrated documentation is aimed at the development of high quality $3 \mathrm{D}$ digital models to improve a greater understanding of European cultural assets.

\section{ACKNOWLEDGEMENTS}

Alberti's project credits

Centro Studi Leon Battista Alberti Foundation, Mantua. Scientific coordinator: Arturo Calzona, Francesco Paolo Fiore, Livio Volpi Ghirardini; team: Federica Cerchiari, Veronica Ghizzi.

DIAPReM Center (Department of Architecture, University of Ferrara) and Consorzio Futuro in Ricerca. Scientific coordinator: Marcello Balzani; team: Federico Uccelli, Guido Galvani, Daniel Blersch, Federico Ferrari, Marco Medici, Daniele Felice Sasso, Paola Puma, Nuccio Bucceri, Piscitelli Flavia, Spenna Antonio, Roberto Carrara, Francesca Concas, Alessandro Grieco.

Public authorities involved: Superintendence for Architectural Heritage and Landscape for the provinces of Brescia, Cremona and Mantua, Municipality of Mantua, Diocese of Mantua, Banca Agricola Mantovana Foundation 


\section{REFERENCES}

Alberti, L. B., 1966. L'architettura (De re aedificatoria), trans. Giovanni Orlandi, notes by Paolo Portoghesi, Milan.

Apollonio, F. I., Gaiani, M., Fallavollita, F., Ballabeni, M., \& Zheng, S., 2014. Bologna Porticoes Project: 3D Reality-Based Models for the Management of a Wide-Spread Architectural Heritage Site. In Euro-Mediterranean Conference. Springer International Publishing, pp. 499-506.

Balzani, M., 2006. Il rilievo morfometrico tridimensionale delle architetture albertiane. In Leon Battista Alberti e l'architettura a cura di Bulgarelli, M., Calzona, A., Ceriana, M., Fiore, F.P.. Cinisello Balsamo, Silvana Editoriale, pp. 178-201.

Bonora, V., Tucci, G., Vaccaro, V., 2005. 3D data fusion and multi-resolution approach for a new survey aimed to a complete model of Rucellai's chapel by Leon Battista Alberti in Florence. In Proc. of CIPA XX Int. Symposium, Turin, Italy, p. 117-121.

Borsi, F., 1996. Leon Battista Alberti: opera completa (1973). Milano, Electa.

Bozzola, S., 2012. La lirica. Dalle origini a Leopardi. Bologna, il Mulino.

Brandi, C., 1956. Il Tempio Malatestiano. Edizioni Radio italiana.

Bulgarelli, M., Calzona, A., Ceriana, M., Fiore, F.P., 2006. Leon Battista Alberti e l'architettura. Cinisello Balsamo, Silvana Editoriale.

Burckhardt, J., 2010. La civiltà del Rinascimento in Italia. Roma, Newton Compton Editori

Calzona, A., Volpi Ghirardini, L., 1994. Il San Sebastiano di Leon Battista Alberti. Firenze, LS Olschki, pp. 219-272.

Cardamone, C., 2006. Josef Frank and the history of architecture: gothic and renaissance, Leon Battista Alberti and Albrech Durer in architectural discourse on neues baven at the beginning of the 1930s. Journal of Art Historiography.

Casalini, E.M., 1967. Il Chiostro grande della SS. Annunziata Nel rifacimento Michelozziano e nella trasformazione del secolo XVI. Firenze, Convento SS. Annunziata.

Casalini, E.M., Parronchi, E., 1977. Le due Cupole: conferenze tenute all'Annunziata il 12 e 13 dicembre 1977. Firenze, Convento SS. Annunziata.

Casalini, E.M., 2015. La SS. Annunziata, la storia del santuario mariano di Firenze. Le origini, le vicende, i monumenti attraverso i secoli. Roma, Curia Generalizia OSM.

De Angelis D'Ossat, G., 1982. Realtà dell'Architettura. Apporti alla sua storia 1933-78. Volume 2. Roma, Carucci.

Di Giulio, R., Maietti, F., Piaia, E., 2016. 3D Documentation and Semantic Aware Representation of Cultural Heritage: the INCEPTION Project. In Proc. of Eurographics Workshop on Graphics and Cultural Heritage. Genova, pp. 195-198.

Docci, M., 2005. Metodologie innovative integrate per il rilevamento dell'architettura e dell'ambiente. Roma, Gangemi.
El-Hakim, S. F., Beraldin, J. A., Picard, M., \& Godin, G., 2004. Detailed 3D reconstruction of large-scale heritage sites with integrated techniques. IEEE Computer Graphics and Applications, 24(3), pp. 21-29.

Fiore, F.P., 2006. Tempio Malatestiano - 1453-1454 e seguenti. In Leon Battista Alberti e l'architettura a cura di Bulgarelli, M., Calzona, A., Ceriana, M., Fiore, F.P., Cinisello Balsamo, Silvana Editoriale, pp. 282-295.

Frank, J., 1910. Über die ursprüngliche Gestalt der kirchlichen Bauten des Leone Battista Alberti.

Grassi, G., 2007. Leon Battista Alberti e l'architettura romana. Milano, FrancoAngeli.

Guidi, G., Russo, M., 2011. Reality-based and reconstructive models: digital media for cultural heritage valorization. SCIRES-IT, 1(2), pp. 71-86.

Heydenreich, L. H., 1930. Die Tribuna der SS. Annunziata in Florenz. Firenze, Mitteilungen des Kunsthistorischen Institutes in Florenz, pp. 268-285.

Hope, C., 1992. The early history of the Tempio Malatestiano. Journal of the Warburg and courtauld institutes.

Landino, C., 1974. Scritti critici e teorici, a cura di R. Cardini, Roma, Bulzoni.

Migliari, R., 2001. Frontiere del rilievo - Dalla matita alle scansioni 3D. Roma, Gangemi.

Ragghianti, C. L., 1965. Tempio Malatestiano, n.74. in Critica d'Arte, pp. 27-39.

Tavernor, R. W., 1985. Concinnitas in the architectural theory and practice of Leon Battista Alberti (Doctoral dissertation, University of Cambridge).

Tavernor, R. W., 1998. On Alberti and the art of building. Yale University Press.

Volpi Ghirardini, L., 2001. L'architettura numerabile di Leon Battista Alberti segno universale di ordine e di armonia. Leon Battista Alberti e il Quattrocento. Firenze, LS Olschki, pp. 234273.

Wittkower, R., 1964. Principi architettonici nell'età dell'Umanesimo. Einaudi, Torino 